\title{
The diversity of cimolestan mammals within the White River Group of South Dakota and Nebraska
}

Clint A. Boyd, Matthew W. Weiler, Mindy L. Householder, and Karew K. Schumaker Acta Palaeontologica Polonica 59 (4), 2014: 771-778 doi: http://dx.doi.org/10.4202/app.2011.0045

The synonymization of the cimolestan taxa Cymaprimadon and Chadronia from the Late Eocene Chadron Formation is consistently upheld, despite a lack of supporting evidence. Here we show that the synonymization is unjustified, owing to distinct differences between these taxa in the mandibular tooth count (1-1-3-3 vs. ?-1-4-3), the identity of the enlarged anterior mandibular tooth (incisor versus canine), and the morphology of the crown of $\mathrm{m} 3$ (e.g., paraconid on $\mathrm{m} 3$ in Cymaprimadon). We also refer a specimen recently collected from the Early Oligocene Brule Formation within the Badlands National Park (BADL 16917) to Chadronia sp., thus making it the youngest occurrence of a pantolestan from North America. Examination of an additional specimen (FMNH UC 349) revealed the presence of a further cimolestan taxon in the White River Group of South Dakota, although the poor quality of the locality and stratigraphic data associated with this specimen precludes erecting a formal name. In total, this study doubles the number of cimolestans from the Late Chadronian and Orellan (Ch4 to Or1) of North America from two to four, and extends the biostratigraphic range of Pantolesta into the North American Oligocene.

Key words: Mammalia, Pantolestidae, Chadronia, Cimolesta, Cymaprimadon, Pantolesta, Chadron Formation, Eocene, White River Group, South Dakota, Nebraska.

Clint A. Boyd [clintboyd@stratfit.org], Department of Geology and Geological Engineering,South Dakota School of Mines and Technology, 501 East St. Joseph Street, Rapid City, South Dakota 57701, USA; Matthew W. Weiler [matthew.weiler@my.und.edu] and Karew K. Schumaker [karew.schumaker@my.und.edu], Department of Geology and Geological Engineering, University of North Dakota, 81 Cornell Street, Grand Forks, North Dakota 58202, USA; Mindy L. Householder [mindy.householder@gmail.com], Badlands National Park, 25216 Ben Reifel Road, Interior, South Dakota 57750, USA. 
This is an open-access article distributed under the terms of the Creative Commons

Attribution License (for details please see creativecommons.org), which permits unrestricted use, distribution, and reproduction in any medium, provided the original author and source are credited.

FaF 